\title{
Physician retirement: gender, geography, flexibility and pensions
}

\author{
Michelle Pannor Silver PhD
}

— Cite as: CMAJ 2017 December 11;189:E1507-8. doi: 10.1503/cmaj.171302

See related article at www.cmaj.ca/lookup/doi/10.1503/cmaj.170231

A Ithough much attention is given to how to meet the increasing demands placed on Canada's health care system as its population ages, there has been little consideration of the needs of aging physicians. In linked research that carefully analyzes work hours leading into retirement among physicians in British Columbia, Hedden and colleagues raise concerns that existent forecasts may overestimate physician supply, which means physician shortages may worsen. ${ }^{1}$ The study's findings point toward earlier retirement among female physicians and physicians working in rural areas. Furthermore, $40 \%$ of physicians decreased their professional activities by $10 \%$ in the three years before retirement. This research highlights several vulnerabilities in the Canadian health care system that must be addressed through careful planning of the physician workforce that pays particular attention to the needs of female physicians and physicians in rural areas, considers mechanisms for creating scaled down or flexible work hours and examines the merits of access to a public pension plan for physicians.

Women now outnumber men in medical schools and family medicine in Canada. ${ }^{2}$ It has been argued that as women become the face of medicine, the issues for women in medicine are a public matter with implications that cross gender lines. ${ }^{3}$ Female physicians are underrepresented in the higher ranks of clinical work and academia, and face challenges that include, but are not limited to, discrimination, harassment and concerns about work-life balance. ${ }^{4}$ Exploring the reasons why women in medicine burn out, the high suicide rates among women in medicine and factors that push women toward retirement earlier in the life course would serve the public interest. Taking good care of female physicians would ultimately benefit the health care system.

In rural communities that find it hard to retain physicians, a physician's retirement can create discontinuity in patient care, contribute to increased wait times and exacerbate tensions in work environments that are already strained. Workforce planners and rural physicians' groups have recognized that Canada's rural communities have unique needs that warrant attention, and measures for physician training have attempted to increase the number of graduating physicians who are likely to work in

\section{KEY POINTS}

- Canada's aging physician population exposes vulnerabilities in the Canadian health care system that ought to be addressed.

- More attention needs to be paid to the needs of women in medicine in terms of both research and policies that address the reasons women exit medicine early.

- Physicians in rural areas face substantial challenges related to succession planning and require more structured assistance to help with this problem.

- Exploring physician participation in a public pension plan, mechanisms for gradual retirement and opportunities to allow for more flexible work hours could help to address some of the problems related to physician retirement.

rural Canada. ${ }^{5}$ Given recommendations in the report by the Truth and Reconciliation Commission of Canada, it is important to consider how physician retirement affects Canada's rural communities. However, physicians in rural settings often struggle to find someone to take over their practices.

Of the hundreds of physicians I have interviewed, one of the most striking was a physician in his eighties who struggled to fulfill what he saw as his obligation to the rural community he had served for over half a century. ${ }^{6}$ In the end, he practically donated his practice to two physicians who eventually agreed to take over his practice, after acknowledging that they could not manage the workload he had maintained alone.

Although some physicians simply avoid retiring because they fear the profound sense of loss of their role as a physician, a substantial number of physicians feel financially unable to retire. ${ }^{7}$ Those in physically demanding specialties, such as surgery and obstetrics, may face age-related decline in performance (e.g., difficulty maintaining a steady hand), yet feel that retirement is not possible for financial reasons. Such concerns are exacerbated by a fee-for-service system for physician renumeration with no public pension.

It may seem aberrant to feel sympathy for the well-paid physician who presumably ought to have been saving money for retirement throughout his or her career. However, medicine is a 
greedy institution, especially when it comes to retirement. ${ }^{8}$ Gradual retirement seems preferable but is frequently not an option given practical constraints. ${ }^{9}$

When a physician has spent his or her life taking care of people at their sickest or most vulnerable, what is to become of the physician who has become vulnerable? When a physician has devoted his or her life to medicine but has failed to invest wisely, how do they retire?

Retirement planning is complicated for all physicians, who generally lack access to a public pension plan. ${ }^{10}$ Physicians tend to face an overwhelming number of obstacles at precisely the point when they should begin independently saving for retirement. The advanced medical training required to become a physician means a late career start, frequently accompanied by the need to pay back student debt. Responsibilities outside of the medical career, such as child care and caregiving, can complicate retirement planning for physicians at various stages of the life course.

Currently, most medical establishments provide little training or support relating to retirement; all planning is left to the physician. Despite the need, few mechanisms for gradual retirement or work sharing exist. Structural changes that would permit more flexible working hours for all physicians would allow parents, those with caregiving obligations, and men and women in medicine who simply want to reduce their hours without leaving medicine entirely, a way to continue working when they might have considered stopping.

Many in society expect physicians to give $110 \%$ to their work and then to figure out how to retire while they are still performing at their best. Justifications have been made to appeal to the public to consider providing access to a public pension plan for physicians. ${ }^{11}$ Currently, over $40 \%$ of Canada's physicians are aged 55 years or older. ${ }^{12}$ Now would be a good time to address practical issues relevant to physician retirement, including accommodating those who would benefit from scaled down or flexible work hours, helping physicians in rural areas with succession planning and reconsidering public pensions for physicians.

\section{References}

1. Hedden L, Lavergne M, McGrail K, et al. Patterns of physician retirement and pre-retirement activity: a population-based cohort study. CMAJ 2017; 189:E1517-23.

2. Basic physician facts. Canadian physician resources - 2017 basic facts. Ottawa: Canadian Medical Association Physician Data Centre; 2017. Available: www.cma.ca/En/Pages/basic-physician-facts.aspx (accessed 2017 Nov. 17)

3. Levinson W, Lurie N. When most doctors are women: What lies ahead? Ann Intern Med 2004;141:471-4.

4. Jagsi R, Griffith KA, Jones R, et al. Sexual harassment and discrimination experiences of academic medical faculty. JAMA 2016;315:2120-1.

5. Rourke J, Task Force of the Society of Rural Physicians of Canada. Strategies to increase the enrolment of students of rural origin in medical school: recommendations from the Society of Rural Physicians of Canada. CMAJ 2005; 172: $62-5$.

6. Silver MP. Retirement and its discontents: how doctors, CEOs, elite athletes, professors, and homemakers struggle with one of life's biggest transitions. New York: Columbia University Press. In press.

7. Silver MP, Hamilton AD, Biswas A, et al. A systematic review of physician retirement planning. Hum Resour Health 2016;14:67.

8. Silver MP, Williams SA. Reluctance to retire: a qualitative study on work identity, intergenerational conflict, and retirement in academic medicine. Gerontologist 2016;Sep 1. pii :gnw142 [Epub ahead of print].

9. Silver MP, Easty LK. Planning for retirement from medicine: a mixed-methods study. CMAJ Open 2017;5:E123-9.

10. Pong RW, Lemire F, Tepper J. Physician retirement in Canada: what is known and what needs to be done. Proceedings of the 10th International Medical Workforce Conference Vancouver: Medical Workforce Conference; 2007 Mar. 20-24; Vancouver. Available: http://documents.cranhr.ca/pdf/10_retCAN.pdf (accessed 2017 Nov. 15).

11. Simpson J. Doctors need salaries and pensions, not fees for service. Globe and Mail [Toronto]. 2015 June 11. Available: https://www.theglobeandmail. com/opinion/doctors-need-salaries-and-pensions-not-fees-for-service/article 24903968/?arc404=true (accessed 2017 Sept. 28).

12. Physicians by age, sex and province/ territory. Ottawa: Canadian Medical Association Physician Data Centre; 2017. Available: https://www.cma.ca/Assets/ assets-library/document/en/advocacy/04-age-sex-prv.pdf (accessed 2017 Sept. 28).

\section{Competing interests: None declared.}

This article was solicited and has not been peer reviewed.

Affiliation: Interdisciplinary Centre for Health and Society, University of Toronto Scarborough, Toronto, Ont.

Correspondence to: Michelle Silver, michelle.silver@utoronto.ca 